\title{
ANTIQUARIAN AND RARE BOOKS IN LONDON AT THE BEGINNING OF THE TWENTY-FIRST CENTURY
}

"Booksellers are Generous liberal-minded men." According to Boswell, Dr. Johnson made this remark in 1756, though anyone remotely acquainted with Johnson will also know that he was equally capable of thinking — and saying — something quite the opposite; it would be imprudent to overlook the possibility of irony here. The London book trade in the eighteenth century was a busy one, and its history is the subject of some of the best research being done on London's culture. There was also a prospering trade in second-hand or "previously owned" books, and a large number of books from previous centuries are often found in eighteenth-century bindings. These books survived into the middle of the twentieth century and still can be found in abundance-if you know where and how to look for them.

London and the surrounding area, or the area within the M25 orbital motorway, is home to well over 350 booksellers. Not all of these have shops, and many work, as I do, from home, seeing visitors by appointment. A very few have only a postal or book fair business. The oldest professional booksellers organization in Britain, the Antiquarian Booksellers' Association (ABA), was founded in 1906 and has a membership of approximately 266. As new members are elected from time to time, and other members cease trading or pass onward to "That Ultimate Bookshop in the Sky," figures are exact for only a short period of time. Of the 266 members, 86 work within the London area. The Provincial Booksellers' Fairs Association (PBFA) has about 740 members, of whom 95 are in the London area. Of course, most members of the ABA also are members of the PBFA. Sheppard's Book Dealers in the British Isles lists more than 2,400 booksellers, and there are probably another 250 or so who are not found-or do not wish to be found-in any directory. Of those listed in Sheppard's, just over 300 are in the London area, with around sixty-five in the outer London area (within the M25 motorway). 
London thus has the lion's share of ABA members, with almost one third located in London, while the London members of the PBFA constitute only about one eighth of its total membership. (This is as it should be, given that the organization was established for provincial booksellers.) Within what one might call the Greater London area, then, there are more booksellers than there are in the whole of the $\mathrm{ABA}$. To be a member of the ABA, one has to be a full-time bookseller whereas the PBFA admits part-time booksellers; but there are full-time and part-time booksellers within the London area who are not members of either organization. By the most generous estimate, however, London still has only a small proportion of the booksellers to be found in the United Kingdom and Ireland, even though a large percentage of booksellers are members of one of the two professional trade organizations, especially so in the case of the ABA.

As a lively and flourishing city for the book trade, and its reputation as a center for antiquarian and rare books, London reflects both the activities of the trade in earlier centuries and the vast increase in the tastes and inclinations of collectors and the budgets of institutional libraries. London obliges the librarian, the collector, and the dealer by encompassing many very different markets within the overall market for "previously owned" books. A few comments about the different kinds of books to be found in London are in order. There is a market for antiquarian books, for rare books, for expensive books, and these categories all overlap; but the most demanding market is not necessarily for the rare, expensive antiquarian book. Let me be as clear as I can about what I mean by an antiquarian book, or a rare book, neither of which is necessarily an expensive book. For me, and for many of my customers and colleagues in the trade, an antiquarian book is one from the hand-press era, or, roughly, books printed before about 1820. It will be immediately and abundantly clear that there are collectors and booksellers for whom this definition is too confining and others for whom it is much too liberal. A rare book can be both an antiquarian book and one difficult to find, but there are numerous unrare antiquarian books: eighteenth-century editions of The Spectator or Clarissa are by no means uncommon, and dealers in antiquarian books can give you dozens of other examples. Coming forward into the twentieth century, one might cite the poems of Isaac Rosenberg (1890-1918); his poems were not printed in great numbers, yet Youth (of which only about one hundred copies were printed) is readily available in three London bookshops and on the Internet. 
Perceptions about the value and scarcity of books persist to the delight and amusement of those in the trade; we are often baffled as well by the vagaries of book-lovers' and book-collectors' suppositions. About two years ago, I was exhibiting at one of the PBFA fairs in Oxford, and I happened to be situated opposite a dealer in "modern firsts"; indeed in this instance, they were hyper-modern firsts. Some of the books had been published only a few years earlier but were all priced well into three figures and sometimes four. Many of the works were by "popular" authors (i.e., those who write for the best-seller fiction market); some academics refer to these books as "soft fiction" and they are also known as "airport novels." One of the works was Minette Walters's first book, The Ice House (1992), an inscribed copy priced at £750. The bookseller was out of his chair more often than not, selling copy after copy of these modern firsts, including Ms. Walters's book. I was having a so-so fair, and I was both pleased and envious (schadenfreude is not unknown to dealers in books) to see a colleague doing well. During a slow part of the second day of the fair, a lady stopped in front of my stand and exclaimed, "Oh, these are very obviously expensive collectors' items." I was exhibiting a good range of antiquarian books, priced between $£ 25$ and $£ 900$, with most in the $£ 100$ to $£ 250$ range: this was, after all, a fair in a university town, and academics are notorious for claiming penury. Although I didn't lose my patience (I hope), I did reply, "Madam, most of these books are priced less than the ones in the shelves opposite me, and they are all at least two hundred or more years older."

Consequently, what I have to say in this article glances at the trade in books from the period before 1820 and in rare books from any period, as well as books that are neither rare nor antiquarian, but which are expensive or are antiquarian and rare and expensive. I have to confess a considerable amount of difficulty with, for example, the trade in modern first editions. I would never argue with the market, but when I see books by J. $\mathrm{K}$. Rowling or Ian Fleming priced-and selling-for more than a respectable copy of the first edition of Johnson's Dictionary (1755), the names Conrad and Galsworthy spring to mind. Not that I personally remember the feeding frenzy for these authors in the twenties, but I can't help feeling that book-collecting history is going to repeat itself with some, if not most, of these authors. However, the craze for the latest modern first edition will probably always be with us, and the avid collector of modern firsts in the eighteenth century who laid in great stores of the works of James Hervey or Henry Mackenzie would probably be happy to remain unknown. I have yet to meet a collector of editions of Luigi Cornaro's 
Discorsi della Vita Sobria, first published in 1558, translated into English as part of a collection of Cornaro's works in 1634, and frequently reprinted thereafter, but I am sure that there must be one, if not several.

Of course, comparisons are not just odious, but invidious; but perhaps one can make them intellectually, or at least culturally, respectable by reasserting that value lies just not in what books sell for, but in how they are perceived by booksellers and customers alike. I don't see many private customers buying or collecting both antiquarian books and popular modern firsts. It is often asserted by members of the trade, as well as by academics and librarians, that the collectors of modern firsts are buying them for display whereas the purchasers might regard them as signifiers of their awareness of, and consonance with, modern culture. Assertions such as these probably take us into arguments about the literary superiority of modern firsts by serious authors (e.g., Julian Barnes) versus "popular" authors. I need hardly say that these designations can and do overlap. Collectors of modern firsts are, of course, spoiled for choice. If they limit themselves just to the first edition of a particular author's books, a complete collection can be assembled in no time at all, given sufficient funds. A complete set of just editio princips of the works of Fleming or Rowling could be assembled in a day's shopping in London whereas W. B. Yeats or P. G. Wodehouse would take rather longer. Most, if not all, book collectors and dealers would consider the latter activity far more fun-the thrill of the chase. Let me cite a specific example, which is, of course, quite literally ephemeral because the market is different at the end of each business day.

A London bookseller is currently offering a first edition, first issue, of J. K. Rowling's first book, Harry Potter and the Philosopher's Stone (1997), with the publisher's original laminated card covers and a later dust wrapper signed by the cover artist Thomas Taylor and personally inscribed by Rowling, for $£ 25,000$. There are two issues of the work, but only a total of 500 were printed, so it can probably justifiably be called a rare book. Similar prices for J. K. Rowling editions can be found outside London and on well-known Internet book-selling sites. Outside London, but still in the UK, one could find (for a brief time because the books have since been sold) a price tag of $£ 48,000$ for proof copies of the first three books by Rowling as they were issued in the United States.

The Rowling phenomenon has been with us a short time, but collectors of Ian Fleming's works have kept demand for his first editions at a high 
level for more than three decades. At a book fair in London in 2002, I was allowed to hold for a few brief seconds a copy of a first edition of Ian Fleming's first book, Casino Royale (1953), an admittedly fine copy in a fine dust wrapper, and the price was pretty much what I expected, $£ 25,000$. Had it been inscribed by the author to a friend, I should imagine that one could have expected to see it priced 30 percent more. Live and Let Die (1954), the second of the Bond novels, is on sale by two or three London booksellers for around $£ 15,000$. Needless to say, all copies are in very good to fine condition with their dust wrappers in moreor-less unspoiled condition. Collectors of fine copies of modern firsts in fine dust wrappers are reliably reported to have nightmares about thieves who don't actually steal the books, but about vandals who merely tear the dust wrappers into small pieces.

I am relating history, not news. Several colleagues who have been in the trade a good deal longer than I have, and whose fathers and grandfathers before them also were booksellers, can remember the market for modern firsts at the end of the 1920s. After the crash of 1929, a copy of Villa Rubein (1900) by John Sinjohn (i.e., John Galsworthy) dropped from $£ 100$ to the price of a Sunday roast (probably about two shillings in 1929). One might have expected something similar after the dot. com bubble burst a few years ago because it was popularly assumed in parts of the book trade that only dot.com millionaires were buying Fleming and Rowling and other modern firsts. If they were, they have not dumped their "collections" on the market, and prices for modern firsts in general seem remarkably stable, at least for the well-known and highly sought-after authors.

Now for the odious part. I was pleasantly surprised to find in the early summer of 2003 that a London dealer was offering a copy of the first edition of Milton's Areopagitica (1644) for about the price of two Harry Potters, £48,000. Admittedly, this copy has several other short pamphlets bound with it, but it seems unlikely that these would have greatly affected the price. One can happily think that Milton is still a name to be reckoned with among wealthy collectors. Of course, the Harry Potter books have more than one hundred million readers worldwide, and not even those who have read Areopagitica would expect to meet more than a handful of people who had even heard of the work.

This is not comparing like with like: Milton was not a novelist (though some of his contemporary readers thought that the argument in Ar- 
eopagitica was little short of narrative fantasy). However, Jane Austen manages to hold her own with Fleming and Rowling, with booksellers in the London area offering first editions of her works at prices between $£ 15,000$ and £50,000 (a fine copy of Pride and Prejudice in contemporary calf). The only novel from the pre- 1820 period certain to command an even higher price than any of Jane Austen's novels, or even fine copies of all her first editions, would be Mary Shelley's Frankenstein (1818). A north London dealer, who has sold two copies of the first edition in recent years, estimates that a first edition of this work could be sold for as much as $£ 150,000$. Copies of the second edition (1823) are on sale in London bookshops for anything from $£ 10,000$ to $£ 22,500$. Second editions of Jane Austen don't fare quite so well, but even copies of her second editions are on offer for more than $£ 10,000$. One work in particular appeals to me, and that is a copy of the second edition of Pride and Prejudice (1813) offered at $£ 15,000$ by a bookseller in the London area. Unlike most Austen novels on offer, this one has survived for its 190 years still in its original boards, uncut. Just as a few collectors do, I go weak at the knees when I see fine copies of books in their original boards, just as they came from the printer. It is a specialized taste, and perhaps one to which academics and booksellers respond more readily than most collectors or librarians. ${ }^{1}$ Collectors of modern firsts might describe this as a weakness/ virtue not all that different from the passion for dust wrappers.

Milton and Austen are useful guides to what a collector might be able to do with a few days to spare in London and vicinity. Again, first editions of all Jane Austen's novels would require only a day's pleasant saunter from shop to shop for a wealthy collector. Supplementing those first editions, with all lifetime editions, first illustrated editions, memorabilia, contemporary works bearing on her life, however tangentially, could keep our putative collector happy and out of mischief for a least a couple of months, if not years. With Milton, the situation is rather different, quite obviously because he wrote so much more. In the case of Milton, I cannot help feeling that the thrill of the chase would be just that much more exciting. First editions of his works are not necessarily uncommon, but the real pleasure in collecting Milton would be that of the later editions and commentaries. In that area, there is a wealth of historical material to choose from (much of it from the eighteenth century), and London antiquarian booksellers have Milton and Miltoniana in abundance.

1. See Jonathan E. Hill, "From Provisional to Permanent: Books in Boards 1790-1840," The Library 21:3 (1999): 147-73. 
For almost thirty years, one of the best features of the London antiquarian book trade for me has been the monthly book fairs held in the Russell Square area. These fairs originated with the PBFA, founded in 1974, though the first fairs were held in a variety of places. In 1983, the fairs established themselves in the Russell Hotel (now rather pretentiously renamed Le Meridien Russell Hotel) in Russell Square and have been there ever since. The fairs were generally held on the second Sunday and Monday of each month, but recently the two-day fairs have occurred only quarterly. The success of these fairs spawned complementary fairs at nearby hotels, the Royal National Hotel and the Bonnington Hotel, both within five minutes walk of the Russell Hotel. The latter two fairs were held only on Sundays. Only members of the PBFA could exhibit at the PBFA fairs, but any respectable bookseller could exhibit at the other fairs.

These fairs all have a number of attractions. At the PBFA fairs, one could more or less depend on seeing the same booksellers, in the same location, month in, month out; the same tended to be true of the other fairs, but these were inevitably the fairs at which booksellers new to the trade first exhibited. Many of the exhibitors at these, and to some extent at the PBFA, are engaged in bookselling only part-time; but many of these part-timers exhibit professionalism and knowledge that should make their full-time colleagues blush. Moreover, at the Russell and Royal National fairs, I can regularly depend on finding a great variety of antiquarian books, more, for example, than I have ever found at the ABAA annual fairs in California. As more than one American bookseller has remarked, "There's a lot of leather in London."

Collectors and booksellers alike attend these fairs eagerly and regularly; one even sees the odd librarian at the fairs, though in every instance that I can remember they are looking for books for their own collections and not for the institutions that employ them. That well-known, civilized, and civilizing British invention, the queue (or line to us Americans), is very much in evidence well before the fairs open. Indeed, when I was exhibiting at these fairs, I could predict with almost unfailing regularity the people who would be first in the queue. On the rare occasions when I tried to correlate presence in the line with books purchased, I came up with no quantifiable result. After the doors had opened, the hopefuls invariably made straight for the same exhibitors month after month.

Probably the greatest attraction of these monthly fairs is that a large number of the exhibitors do not have their books listed on any of the In- 
ternet book-selling sites. Or, if they have books listed, they often bring to the fairs books that they don't want to catalogue or that have been acquired in such bulk as to make rapid cataloguing impossible. Those for whom this is a part-time activity often would not have the time to catalogue the books properly and upload them to the Internet. Moreover, many are interested in a quick turnover and have neither the time nor the expertise to "research" a book's scarcity, utility, or desirability to a particular collector or library. I won't say that there are bargains to be had from every exhibitor, but most of the books are reasonably or even modestly priced. It is difficult, so long as one is in a book-buying mood, to come away from these fairs without one or two items that yield a nice profit for a bookseller or pleasure for the collector.

Another of the attractions of these fairs is that they are seldom patronized by some well-known names in the London antiquarian book trade. Occasionally, a large shop whose name would ring a bell with any serious librarian or collector will exhibit at these fairs, but this is not a common occurrence. Nor do they attend the fairs to buy, which means that the private collector and the "sole proprietor" bookseller are not often in competition with specialized dealers with large stocks and similarly large overheads. These fairs thus give the dedicated or casual collector, as well as individual booksellers, an opportunity to see a wide range of books at prices that range from the unbelievably inexpensive to reasonable. Occasionally, an inexperienced (or greedy) exhibitor will ask what one might call a "standard" price for certain well-known items. For example, a first edition of, say, Gulliver's Travels might be offered for about the same price that one would expect to pay in one of the large and famous shops in London. With experience, most exhibitors learn that prices at this kind of book fair are not the same as catalogue or shop prices.

The pricing of well-known books at these fairs by smaller booksellers, usually sole proprietors, and the reaction of collectors is a constant source of mystery, perplexity, and amusement. Time and time again, I have seen collectors pass up a copy of a very desirable book at these fairs, only for it to be snapped up in seconds by a dealer who then sells it to another dealer, who then sells it to exactly the same kind of collector who turned it down in the first place. Indeed, I know of several cases in which a book has been seen by a serious collector who has, for some reason, felt uncomfortable about buying it at that time and from that dealer. Later, weeks or months, the same book has been offered to said serious collector, or he or she has seen it in a famous shop, and the 
sale has been made. Booksellers are no doubt suitable cases for treatment, but collectors can sometimes seem to be more so.

One of the more predictable features of these monthly fairs is the specialized and dedicated collector. Any dealer exhibiting at these fairs knows who is going to ask him or her for books on chess, or books on Cyprus, or on watches and clocks, or on three-wheeled bicycles. Perhaps that last one is a bit fanciful, but the most persistent collectors seem to be those who are most likely to go away from the fairs empty-handed. One admires their staying power, but their cumulative disappointment must be considerable.

In some instances, I believe that this disappointment is almost self-willed. I was talking to a colleague at a book fair when a potential customer took a small book off his shelves. It was, in fact, a copy of Cornaro's Discorsi published in Paris in 1646, one of those books that no book fair, as I hinted above, should be without. The book was in a contemporary calf binding, a little rubbed, but still in good, collectable condition, modestly priced at $£ 45$, which seemed to me rather a bargain. It was published in Paris by Pierre Des-Hayes, whose imprints are rather attractive and collected. Mr. Customer Would-Be exclaimed that he had three other imprints by this publisher. My colleague replied, "Well, now you can have a fourth." "Oh," Mr. Would-Be said, "I'd like to, but it's just too expensive." At this stage, I can't recall what emotions or impulses my colleague and I repressed, but I think one of us remarked that he would be unlikely to find a cheaper copy. In any case, Mr. Would-Be left empty-handed. Just to complete the story, Reader: I bought the book. This is not an uncommon occurrence, and dealers who have been in the trade all their lives can doubtless relate similar tales.

A more general collector, then, who set out to collect just books printed before 1800, without being too fussy as to author, subject, or condition would probably run out of the energy to carry the books home before he or she ran out of books to buy. A few years ago, a collector of my acquaintance set out to get an example, on a fairly limited budget, of at least one book printed each year from about 1490 to 1800. Two years ago, without having spent more than $£ 300$ on any book, and most books were considerably less than that, usually in two figures, his collection was complete from 1622 to 1800; in the period between 1500 and 1621, he had only twenty-eight gaps; and he had managed to buy five incunabula as well, one of those being his most expensive purchase. Many of these he found at these monthly fairs, and I suspect that if he had confined himself to purchases just from these fairs, he would have done almost as well. 
It is still possible, then, to build a library of books printed before 1800 without incurring the kind of expenditure that alienates partners or has a wholly negative effect on whatever budget one may have. For one thing, very few exhibitors at these fairs take credit cards, preferring checks or cash, so the temptation to max out a credit card in one day is minimal. Giving myself a putative budget of $£ 500$ as a maximum expenditure for the fairs, I found a total of nineteen books printed in the eighteenth century that I would have been happy to buy had I been starting a collection of eighteenth-century books. Some of them were not in wonderful shape, with covers detached in some instances or with other serious binding flaws, some with stained or worn pages, but all acceptable as "working copies" or "reading copies." I suspect that another person, with more options and more persistence in looking at virtually every likely leather-bound book, could probably have doubled that number, especially if he or she was willing to buy odd volumes.

I hasten to say that I don't know of a collector who has ever done this, that is, setting out to collect eighteenth-century books almost willynilly, without regard to subject or condition. Usually a collection has some focus within that period, even if it's just English literature, which is reasonably plentiful, though a scholar-collector is unlikely to prefer a late eighteenth-century reprint of Tom Jones as a scholarly copy to the Wesleyan edition. However, one can find any number of books where no modern edition is available or where it is possible to buy a working copy of something like The Spectator for considerably less than Bond's edition, but which can be used as a research tool until the time comes for preparing a proper, scholarly paper from a proper, scholarly text.

These fairs help to make London a unique source for antiquarian books, and many of us are probably not as grateful as we should be for the existence of these fairs. The Internet has apparently had some effect on the numbers who now choose to exhibit because the number of dealers exhibiting at the PBFA fair has dwindled from the peak years, when dealers often felt lucky just to have the opportunity to exhibit in London once a month. We have become accustomed to our good fortune in having around 100,000 books to choose from each month, and perhaps don't realize how grateful book collectors and dealers in other parts of the world would be to have such opportunities.

In 2003, London had less to offer the collector of second-hand books than it had thirty or forty years ago. Rents, property taxes, and the cost 
of property in central and suburban London have all militated against the large bookshop with mostly cloth-bound second-hand books. There is still a generation of collectors and enthusiasts, of course, who complain that eighteenth-century books used to be second-hand books, until the exponential expansion of American and Japanese university libraries. I believe it was John Carter who replied to ruminations by book dealers that there would soon be no antiquarian books left and that we would all be congratulating ourselves on being able to buy a first edition of In Memoriam for £50. He was probably not far off the mark, though a persistent Tennyson collector could probably find several copies in London shops for less than $£ 100$.

The paradox is that London is now probably a better place to look for genuinely rare and antiquarian books than it was thirty or forty years ago. The prices these books command mean that it is still financially feasible for booksellers to maintain premises in London because they are dealing almost exclusively in books that command high prices. Of course, there are still shops with a good general range of books, their bread and butter, so to speak, but to keep a business going in London, a bookseller would certainly have to have a number of books with prices in four or five figures, or more.

One of the most interesting changes to me in those thirty or forty years has been in attitudes of antiquarian booksellers. When I first began visiting London bookshops in the late 1960s, I was seldom encouraged to look at the stock. (Martin Hamlyn of Peter Murray Hill was an honorable exception and visiting his shop was a genuine pleasure.) I often felt that I needed to provide a personal recommendation from some auspicious dignitary, as well as several personal references, and then my application to be allowed to look at the antiquarian books would be considered. Even writing in advance to various London booksellers to say that I would be coming to London and would like to see their books often did not get me any further than the front desk. I never knew: I might be permitted to spend half a day browsing through the "back room(s)" and making some choices, but I might just be told that the few sad books on display were all that were available for sale at that particular moment.

My most vivid experience of this attitude came from a bookseller who did, in fact, allow me to roam freely around his stock, and I always found books to buy. On one occasion, there was a large number of books 
in my area and for once my bank account was in a position to cope with this pleasant exigency. My pile of books to purchase was growing and was much larger than it had been on previous occasions. When the proprietor resurfaced to see how I was getting on, he exclaimed, "But that's too many!" or words to that effect. I was told that I had to stop then and that I couldn't choose any more books. Indeed, some were removed from the pile and returned to the shelves and my purchases reduced to what the proprietor thought I ought to be allowed to buy. Needless to say, that was the last time I made any purchases from that particular bookseller. I might have been cutting off the front cover in order to spite the text, but I really could not understand that attitude.

Remnants of the attitude still exist, not just in the antiquarian and rare book trade, but in large parts of commerce in London and throughout the UK: A customer is someone who is allowed to purchase goods from you. It was not an attitude that I can remember having encountered while I lived in the United States, and I am happy to see that it now seems to be on its last legs in the London book trade. The economics of the book trade have made it simply not feasible to ignore or to condescend to potential customers, though one feels that some booksellers still would like to. Moreover, London booksellers can no longer depend on regularly buying large country house libraries or private collections as they once could. These days, the libraries are likely to be consigned to an auction house, and in any case there simply aren't so many of them. The large stock in an undisclosed warehouse that could be passed through several generations of booksellers doesn't seem to exist any more. I would, of course, be delighted to be proved wrong about this and would be only too happy to accept an invitation to browse and buy at will.

At the beginning of the twenty-first century, London seems to me a genial and congenial place to look for antiquarian and rare books. It might be that I am now on the other side of the counter, so to speak, but I almost always find my contact with other members of the trade pleasant and stimulating. Many of us have come into the trade from other careers. Not surprisingly, a lot of us have been academics or librarians, though there are doctors, economists, civil servants, and various other trades and professions in our backgrounds. Also, I find most of my colleagues in the trade happy to share their expertise and knowledge and to admit their ignorance when they have no idea. They also are eager to cultivate new collectors and, in general, are more approachable and sales 
oriented than perhaps they were in the past. Certain places in central London (e.g., Cecil Court) that have been havens for booksellers and collectors alike are still in operation, although the numbers of books are somewhat diminished.

The Internet and various trade directories make it much easier to plan a shopping expedition or to see if a particular bookseller has the sort of book one is interested in. Internet listings have to be used cautiously as a guide to a London bookseller's stock: Shops in particular do not necessarily upload to the various book-selling sites all their stock, and, as the London real estate agencies say, "early viewing is advised." Most of us who cherish books prefer to handle them before we buy them, something that is not possible when you are miles away from any bookstore. There are book towns in Wales (Hay-on-Wye and, very recently, Blaenavon) and Scotland (Wigtown). No one asks why England doesn't have one: It does, and it's called London, and I know of no better place to buy books, sell books, and look at books. 